\title{
Focus on Mammalian Embryogenomics Dynamic changes in messenger RNA profiles of bovine endometrium during the oestrous cycle
}

\author{
Katrin Mitko ${ }^{1,2}$, Susanne E Ulbrich ${ }^{3}$, Hendrik Wenigerkind ${ }^{4}$, Fred Sinowatz ${ }^{5}$, Helmut Blum², \\ Eckhard Wolf ${ }^{1,2}$ and Stefan Bauersachs ${ }^{1,2}$ \\ ${ }^{1}$ Institute of Molecular Animal Breeding and Biotechnology and ${ }^{2}$ Laboratory for Functional Genome Analysis \\ (LAFUGA), Gene Center, LMU Munich, Feodor-Lynen-Strasse 25, 81377 Munich, Germany, ${ }^{3}$ Physiology- \\ Weihenstephan, Technical University of Munich, Weihenstephaner Berg 3, 85354 Freising, Germany, ${ }^{4}$ Bavarian \\ Research Centre for Biology of Reproduction, Hackerstr. 27, 85764 Oberschleissheim, Germany and ${ }^{5}$ Institute of \\ Veterinary Anatomy, Histology and Embryology, LMU Munich, Veterinärstr. 13, 80539 Munich, Germany
}

Correspondence should be addressed to S Bauersachs; Email: bsachs@Imb.uni-muenchen.de

\begin{abstract}
During the oestrous cycle, the bovine endometrium exhibits characteristic morphological and functional changes, which are mainly induced by progesterone $\left(\mathrm{P}_{4}\right)$, oestrogens and oxytocin. We studied the response of the endometrium to this changing hormonal environment at the transcriptome level using a custom-made cDNA microarray. Endometrium samples were recovered from Simmental heifers on days 0 (oestrus), 3.5 (metoestrus), 12 (dioestrus) and 18. The latter group was divided into animals with high (late dioestrus) and low $P_{4}$ levels (preoestrus). Significance analysis of microarrays revealed 269 genes exhibiting significant changes in their transcript levels during the oestrous cycle in distinct temporal patterns. Two major types of expression profiles were observed, which showed the highest mRNA levels during the oestrus phase or the highest levels during the luteal phase respectively. A minor group of genes exhibited the highest mRNA levels on day 3.5. Gene ontology (GO) analyses revealed GO categories related to extracellular matrix remodelling, transport, and cell growth and morphogenesis enriched at oestrus, whereas immune response and particular metabolic pathways were overrepresented at dioestrus. Generation of gene interaction networks uncovered the genes possibly involved in endometrial remodelling (e.g. collagen genes, TNC, SPARC, MMP2, MEP1B, TIMP1, TIMP2, HTRA1), regulation of angiogenesis (e.g. ANGPTL2, TEK, NPY, AGT, EPAS1, KLF5), regulation of invasive growth (e.g. PCSK5, tight junction proteins, GRP, LGALS1, ANXA2, NOV, PLAT, MET, TDGF1, CST6, ITGB4), cell adhesion (e.g. MUC16, LGALS3BP) and embryo feeding (e.g. SLC1A1, SLC11A2, SLC16A1, SEPP1, ENPP1). Localisation of mRNA expression in the endometrium was analysed for CLDN4, CLDN10, TJP1, PCSK5, MAGED1, and LGALS1.

Reproduction (2008) 135 225-240
\end{abstract}

\section{Introduction}

Throughout the oestrous cycle and during pregnancy, the bovine endometrium exhibits characteristic morphological and functional changes, which are mainly regulated by progesterone $\left(\mathrm{P}_{4}\right)$, oestrogens and oxytocin (Spencer et al. 2004b). With respect to the typical

This article was presented at the 2nd International Meeting on Mammalian Embryogenomics, 17-20 October 2007. The Co-operative Research Programme: Biological Resource Management for Sustainable Agricultural Systems of The Organisation for Economic Cooperation and Development (OECD) has supported the publication of this article. The meeting was also sponsored by Le conseil Régional Ilede-France, the Institut National de la Recherche Agronomique (INRA), Cogenics-Genome Express, Eurogentec, Proteigene, Sigma-Aldrich France and Diagenode sa. characteristics of the endometrial structure and function, the bovine oestrous cycle can be divided into four stages: preoestrus, oestrus, metoestrus and dioestrus. At oestrus, $\mathrm{P}_{4}$ levels are low, whereas oestrogens are elevated. This leads to increased blood circulation and oedematisation of the mucosa and to a high contractility of the smooth musculature. The highly cuboidal endometrial epithelium consists of both ciliated cells and secretory cells, which produce oestral mucus. The uterine glands are elongated as a result of the mucosal oedema (Ruesse \& Sinowatz 1998). Oestradiol levels start to decrease just before the luteinising hormone (LH) surge and ovulation. Following ovulation, $\mathrm{P}_{4}$ levels increase during the 3-day period of metoestrus due to the formation of the new corpus luteum. This phase is characterised by low levels of both $\mathrm{P}_{4}$ and oestradiol in the peripheral blood. Mucosal oedema and 
contractility of the smooth musculature are declining during metoestrus. During dioestrus, there are high $\mathrm{P}_{4}$ and low oestradiol levels and the surface epithelial cells are flat. The highly active and proliferating uterine glands secrete uterine milk or histotroph. Its best characterised constituent is uteroferrin, an iron-containing acidic phosphatase, which is involved in the transport of iron to the conceptus. A group of basic protease inhibitors, which have considerable sequence homology to bovine pancreatic trypsin inhibitor (aprotinin), are supposed to control intrauterine proteolytic events initiated by the conceptus. Another secreted basic protein is lysozyme, which is presumed to have an antibacterial effect (Roberts \& Bazer 1988). If no embryo is present, luteolytic pulses of prostaglandin $\mathrm{F}_{2 \alpha}\left(\mathrm{PGF}_{2 \alpha}\right)$ lead to the regression of the ovarian corpus luteum after day 18 resulting in a strong decrease in $\mathrm{P}_{4}$ during preoestrus and the entry into a new ovarian cycle (Goff 2004). In contrast, during early pregnancy, the bovine embryo produces interferon- $\tau$ (IFNT) as main anti-luteolytic pregnancy recognition signal that prevents luteolysis and the corpus luteum continues production of $\mathrm{P}_{4}$ as a prerequisite for further development and implantation of the conceptus (Spencer et al. 2004a).

There are a number of studies using microarrays for the investigation of gene expression changes in the endometrium during the sexual cycle in humans (Horcajadas et al. 2007), rhesus monkeys (Ace \& Okulicz 2004) and mice (Tan et al. 2003). Furthermore, in a first transcriptome study of bovine endometrium during the oestrous cycle, more than 130 genes have been identified as differentially expressed between oestrus and dioestrus (Bauersachs et al. 2005). $\mathrm{P}_{4}$-induced genes have been characterised in sheep endometrium in a study where cyclic ewes were treated with $\mathrm{P}_{4}$ and endometrial tissue samples were analysed using a custom ovine cDNA array (Gray et al. 2006). However, there are no systematic large-scale gene expression studies comparing more than two stages of the sexual cycle. Only recently, human endometrial biopsy samples were collected during the cycle and analysed in a microarray study with the objective to assign the samples to specific stages of the cycle based on their relative mRNA expression profiles (Ponnampalam et al. 2004).

In the present study, a custom-made bovine oviduct and endometrium (BOE) cDNA array (Bauersachs et al. 2007) was used to generate mRNA expression profiles of the bovine endometrium during the oestrous cycle. Molecular pathways were identified as related to the biological functions of the endometrium in the context of recognition and establishment of early pregnancy.

\section{Results}

The animals slaughtered during the oestrous cycle were subdivided into five groups, each with four animals: days 0 , $3.5,12$ and 18 with high $\mathrm{P}_{4}$ levels $(>2.8 \mathrm{ng} / \mathrm{ml} ; 18 \mathrm{P} 4 \mathrm{H})$, and day 18 with low $\mathrm{P}_{4}$ levels $(<0.7 \mathrm{ng} / \mathrm{ml} ; 18 \mathrm{P} 4 \mathrm{~L})$. To analyse gene expression changes in the bovine intercaruncular endometrium during the oestrus cycle at the level of the mRNA, a custom-made cDNA array (BOE array) was used (Bauersachs et al. 2007). This array contains 1344 cDNA fragments and 96 oligonucleotides representing 950 different genes. Most of them were identified as differentially expressed in the endometrium during early pregnancy and the oestrous cycle and in oviduct epithelial cells in several previous studies (Bauersachs et al. 2003, 2004, 2005, 2006, Klein et al. 2006). RNA of the intercaruncular endometrial tissue samples, derived from the middle part of the ipsilateral uterine horn, was used for the preparation of ${ }^{33} \mathrm{P}$-labelled probes. In total, $20 \mathrm{BOE}$ arrays were hybridised and evaluated. Quality control (distance matrix and heatmap; BioConductor package geneplotter) of normalised data revealed one hybridisation as an outlier leading to the exclusion of one day 12 sample from the analyses of microarray results. For the identification of mRNAs with significant changes of their concentration in the endometrium during the oestrous cycle, normalised data were analysed with the 'significance analysis of microarrays method (SAM, Multiclass, false discovery rate (FDR) 1\%; Tusher et al. 2001).

This analysis revealed 427 cDNA fragments or oligonucleotides with significant changes of hybridisation signals during the oestrous cycle. These fragments corresponded to 269 different genes, 267 of them with known or inferred function (Supplementary Table 1, which can be viewed online at www.reproductiononline.org/supplemental). For some cDNAs, no bovine mRNA sequence was found in the GenBank, but the putative human orthologous gene was identified. Two cDNAs could not be assigned to any sequence in the GenBank database and to the bovine genome sequence.

Data from the significant genes were used for cluster analyses. First, data of 19 samples were clustered according to the genes and samples to characterise the differences between the analysed stages of the cycle (Supplementary Figure 1, which can be viewed online at www.reproduction-online.org/supplemental). The samples clustered in three major groups, consisting of day 0 and day 18P4L (Supplementary Figure 1, left), day 3.5 (middle) and day 12 and day $18 \mathrm{P} 4 \mathrm{H}$ animals (right) respectively. The third group split into two subgroups corresponding to the day 12 and day $18 \mathrm{P} 4 \mathrm{H}$ animals. The day $18 \mathrm{P} 4 \mathrm{~L}$ and day 0 animals did not split into two distinct separate groups. A two-class SAM analysis for days 0 and 18P4L revealed only two transcripts, which were significantly more abundant in the $18 \mathrm{P} 4 \mathrm{~L}$ animals. The cluster analysis in Supplementary Figure 1 shows that the greatest difference is present between the animals of the oestrous (days 18P4L and 0 ) and dioestrus stages (day 12).

For the identification of groups of genes showing similar dynamic patterns in their expression levels during the oestrous cycle, a second cluster analysis was performed. Different numbers of clusters from five to ten were tested and the number of seven clusters was found best to 


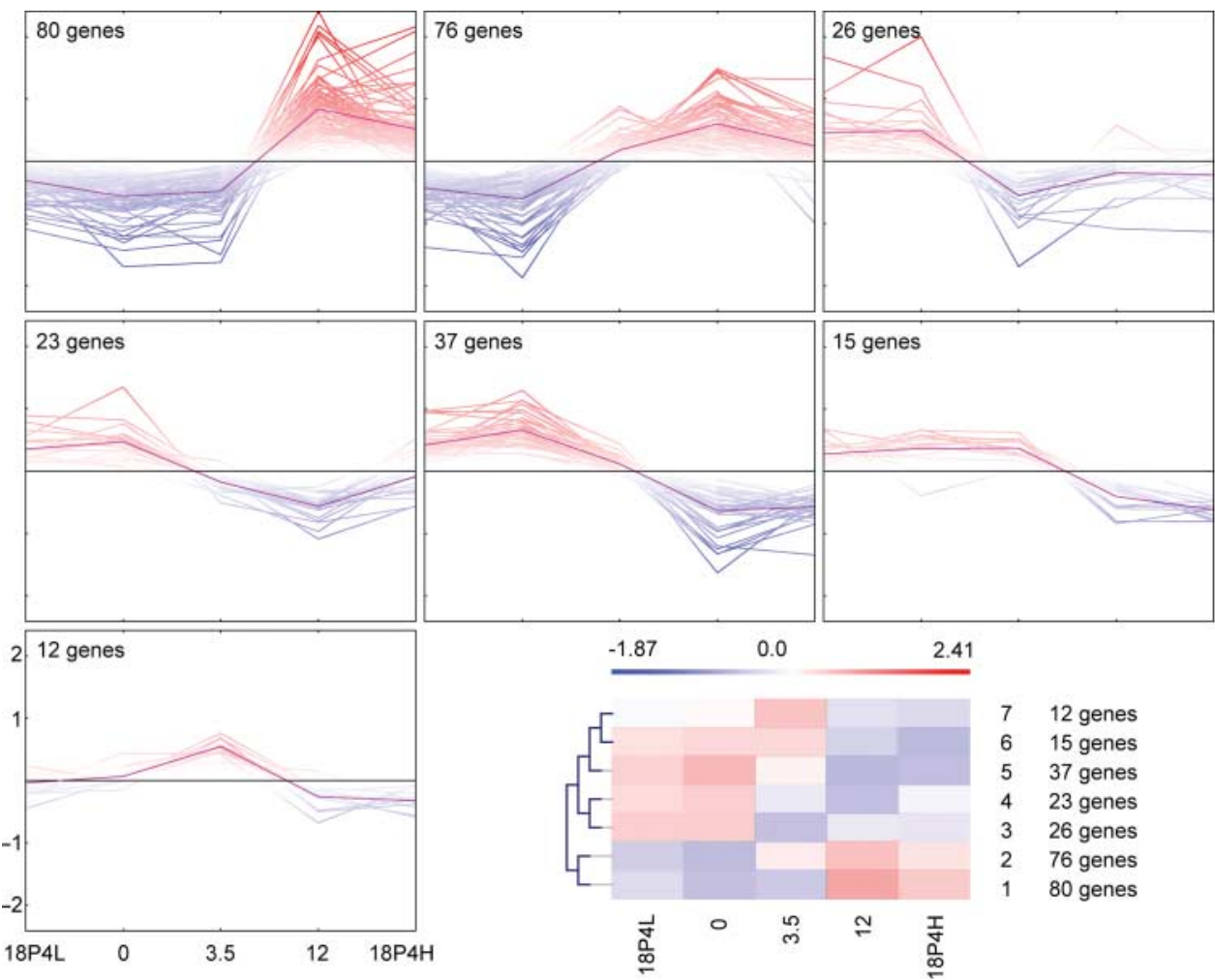

Figure 1 Clusters of similar expression profiles during the oestrous cycle. Genes were clustered according to the correlation of their expression profiles during the oestrous cycle using selforganising tree algorithm (SOTA, MultiExperiment Viewer 4.0). The SOTA dendrogram (bottom right) shows the similarity between clusters. represent similar expression profiles (Fig. 1). In the first cluster (80 genes), the mRNA levels are low at oestrus (days 18P4L and 0) and metoestrus (day 3.5) and rise on day 12 (dioestrus). Cluster 1 also contains a number of genes with increasing mRNA levels from days 12 to $18 \mathrm{P} 4 \mathrm{H}$ but a twoclass SAM analysis between the groups, days 12 and $18 \mathrm{P} 4 \mathrm{H}$, revealed almost no significantly higher signals at day $18 \mathrm{P} 4 \mathrm{H}$ compared with day 12 . In the second cluster (76 genes), the mRNA levels are also low at oestrus (days 18P4L and 0 ) but are already increased on day 3.5. Clusters 3 (26 genes), 4 (23 genes) and 5 (37 genes) have all their highest expression levels at days $18 \mathrm{P} 4 \mathrm{~L}$ and 0 (oestrus stage). Cluster 3 differs from 4 and 5 therein that the mRNA levels are decreased at days $3.5,12$ and $18 \mathrm{P} 4 \mathrm{H}$ with the lowest levels at day 3.5. Clusters 4 and 5 look quite similar, but in cluster 4 mRNA levels are lower at day 3.5 compared with cluster 5 and start to increase at day $18 \mathrm{P} 4 \mathrm{H}$. Cluster 6 (15 genes) contains genes that have higher mRNA levels from days $18 \mathrm{P} 4 \mathrm{~L}$ to 3.5 (oestrus to metoestrus) and low levels at days 12 and $18 \mathrm{P} 4 \mathrm{H}$. Cluster 7 consists of 12 genes with the highest mRNA levels at day 3.5. However, some genes, which have also their highest expression at day 3.5, were assigned to the second cluster since - in contrast to cluster 7 - their mRNA concentrations are higher at dioestrus compared with oestrus.

Ninety-four of the genes showed their highest mRNA expression level in the groups, days 18P4L and 0; 23 genes at day $3.5 ; 112$ genes at day 12 ; and 40 genes at day $18 \mathrm{P} 4 \mathrm{H}$.

The results of the cDNA array hybridisation were verified and absolutely quantified by the use of quantitative real-time RT-PCR (qPCR). The same RNA samples as for the array hybridisation were used. Eleven genes were selected for the validation of different types of mRNA expression profiles revealed by the microarray analysis. Furthermore, most of the genes were chosen due to their proposed functions in the context of maternal fertility and establishment of pregnancy. Table 1 shows the relative expression data obtained by $\mathrm{qPCR}$ and the corresponding array data. The table shows mean fold changes between various stages of the oestrous cycle when compared with the stage with the lowest expression (set to 1.0). Array and qPCR data correlated well. However, two of the analysed mRNAs showed no significant $(P<0.05)$ changes according to the qPCR.

For the analysis of gene ontology $(\mathrm{GO})$ classifications and pathway analyses, clusters 1 and 2 (high expression levels at dioestrus) and clusters 3, 4, 5 and 6 (high expression levels at oestrus) were combined respectively. Enriched and underrepresented GO categories (significance threshold: $\geq 3$ genes, $P \leq 0.01)$ were identified using GO tree machine (GOTM) and OntoExpress respectively. Analyses were done based on Entrez Gene IDs of the putative human orthologous genes. Redundant and unspecific categories were removed. Enriched GO categories for genes with higher expression at oestrus are shown in Table 2. GO categories related to extracellular matrix (ECM) remodelling (e.g. 'collagen', 'extracellular region', 'ECM'), transport processes (e.g. 'transport', 'intracellular transport', 'establishment of protein localisation', 'endoplasmic reticulum', 'cytoskeleton-dependent 
Table 1 Validation of array results using real-time RT-PCR.

\begin{tabular}{|c|c|c|c|c|c|c|c|c|}
\hline Gene & Gene name & Analysis & Day $18 \mathrm{P} 4 \mathrm{~L}$ & Day 0 & Day 3.5 & Day 12 & Day $18 \mathrm{P} 4 \mathrm{H}$ & $P$ value* \\
\hline \multirow[t]{2}{*}{ CLDN10 } & Claudin 10 & Array & 14.1 & 14.8 & 7.2 & 1.3 & 1.0 & $<0.001$ \\
\hline & & qPCR & 28.3 & 33.9 & 13.0 & 1.2 & 1.0 & $<0.001$ \\
\hline \multirow[t]{2}{*}{ IRF1 } & Interferon regulatory factor 1 & Array & 1.5 & 1.0 & 2.0 & 2.5 & 3.4 & 0.001 \\
\hline & & qPCR & 1.3 & 1.0 & 1.3 & 1.2 & 2.0 & 0.064 \\
\hline \multirow[t]{2}{*}{$L G A L S 1$} & Galectin-1 & Array & 2.6 & 4.0 & 2.1 & 1.1 & 1.0 & $<0.001$ \\
\hline & & qPCR & 3.2 & 5.2 & 2.0 & 1.1 & 1.0 & $<0.001$ \\
\hline \multirow[t]{2}{*}{ PLA2G10 } & $\begin{array}{l}\text { Phospholipase A2, group X } \\
\text { (secreted phospholipase A2) }\end{array}$ & Array & 2.4 & 1.0 & 2.1 & 8.1 & 3.9 & $<0.001$ \\
\hline & & qPCR & 2.2 & 1.0 & 3.5 & 5.3 & 9.7 & $<0.001$ \\
\hline \multirow[t]{2}{*}{ PFN1 } & Profilin 1 & Array & 2.2 & 2.5 & 1.3 & 1.0 & 1.6 & 0.002 \\
\hline & & qPCR & 2.7 & 2.5 & 1.0 & 1.0 & 1.2 & 0.006 \\
\hline \multirow[t]{2}{*}{ SERPING1 } & C1 inhibitor & Array & 1.9 & 1.0 & 1.9 & 5.8 & 4.0 & $<0.001$ \\
\hline & & qPCR & 1.5 & 1.0 & 1.7 & 2.0 & 3.6 & 0.008 \\
\hline \multirow[t]{2}{*}{ STC1 } & Stanniocalcin 1 & Array & 3.3 & 3.4 & 1.0 & 1.3 & 1.8 & 0.001 \\
\hline & & qPCR & 8.9 & 4.3 & 1.0 & 1.0 & 2.8 & 0.001 \\
\hline \multirow[t]{2}{*}{ TDGF1 } & $\begin{array}{l}\text { Teratocarcinoma-derived } \\
\text { growth factor } 1 \text { (Cripto- } 1 \text { ) }\end{array}$ & Array & 1.1 & 1.0 & 1.0 & 28.0 & 1.4 & $<0.001$ \\
\hline & & qPCR & 1.6 & 1.0 & 1.0 & 88.8 & 1.8 & $<0.001$ \\
\hline \multirow[t]{2}{*}{$T N C$} & Tenascin C (hexabrachion) & Array & 10.3 & 11.8 & 4.9 & 1.0 & 1.7 & $<0.001$ \\
\hline & & qPCR & 27.0 & 46.8 & 14.1 & 1.0 & 2.3 & $<0.001$ \\
\hline \multirow[t]{2}{*}{ TJP1 } & $\begin{array}{l}\text { Tight junction protein } 1 \text { (zona } \\
\text { occludens 1) }\end{array}$ & Array & 1.5 & 1.0 & 2.9 & 3.5 & 2.2 & 0.002 \\
\hline & & qPCR & 1.0 & 1.0 & 1.5 & 1.2 & 1.1 & 0.219 \\
\hline
\end{tabular}

*P value for array data.

intracellular transport'), cell growth and morphogenesis (e.g. 'insulin-like growth factor (IGF) binding', 'regulation of cell growth', 'cell morphogenesis') and cell shape (e.g. 'cytoskeleton organisation and biogenesis', 'cytoskeletal part', 'actin filament', 'microtubule-based movement') were found. Table 3 shows enriched GO categories for genes with higher mRNA levels at dioestrus. Overall, less and completely different enriched categories were found compared with oestrus. The majority of enriched $\mathrm{GO}$ categories belonged to the term 'response to stimulus', which comprises subcategories such as 'immune response', 'response to chemical stimulus', 'B-cell-mediated immunity' and 'antigen processing and presentation of endogenous antigen'. Furthermore, a number of distinct metabolism categories (e.g. 'lipid catabolism', 'xenobiotic metabolic process', 'monooxygenase activity', 'TCA cycle') were obtained. In addition to the GO analysis, the KEGG pathway database was searched for the identified genes. Genes with higher mRNA levels at oestrus were assigned to 42 pathways and those with higher expression levels at dioestrus to 103 pathways. Considering only pathways where at least two genes were assigned, 14 were obtained at oestrus and 43 at dioestrus. The highest numbers of genes with increased mRNA levels at oestrus were assigned to the pathways 'focal adhesion' (nine genes), 'cell communication' (eight

Table 2 Quantitatively enriched gene ontology (GO) categories for genes up-regulated at oestrus (day 0/day 18P4L).

\begin{tabular}{|c|c|c|c|}
\hline GO category & Genes & $P$ value & Tool \\
\hline Extracellular region & 29 & $<0.001$ & OntoExpr ${ }^{\mathrm{a}}$ \\
\hline Transport & 28 & $<0.001$ & GOTM $^{b}$ \\
\hline Extracellular matrix & 13 & $<0.001$ & GOTM \\
\hline Intracellular transport & 13 & $<0.001$ & GOTM \\
\hline Establishment of protein localisation & 10 & 0.005 & GOTM \\
\hline Endoplasmic reticulum & 10 & 0.008 & OntoExpr \\
\hline Cytoskeletal part & 9 & 0.005 & GOTM \\
\hline Regulation of cell growth & 8 & $<0.001$ & OntoExpr \\
\hline Cell morphogenesis & 8 & 0.001 & GOTM \\
\hline Cytoskeleton organisation and biogenesis & 8 & 0.003 & GOTM \\
\hline IGF binding & 5 & $<0.001$ & GOTM \\
\hline Cytoskeleton-dependent intracellular transport & 5 & $<0.001$ & GOTM \\
\hline Growth factor activity & 5 & 0.004 & OntoExpr \\
\hline Microtubule-based movement & 4 & $<0.001$ & OntoExpr \\
\hline Microsome & 4 & 0.005 & OntoExpr \\
\hline Protein disulphide isomerase activity & 3 & $<0.001$ & GOTM \\
\hline Actin filament & 3 & 0.001 & GOTM \\
\hline Neuropeptide signalling pathway & 3 & 0.003 & OntoExpr \\
\hline 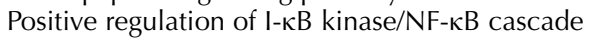 & 3 & 0.005 & OntoExpr \\
\hline
\end{tabular}

${ }^{\mathrm{a} O n t o E x p r e s s .}{ }^{\mathrm{b}} \mathrm{GO}$ tree machine. 
Table 3 Quantitatively enriched gene ontology (GO) categories for genes up-regulated at dioestrus (day 12/day 18P4H).

\begin{tabular}{|c|c|c|c|}
\hline GO category & Genes & $P$ value & Tool \\
\hline Response to stimulus & 45 & $<0.001$ & OntoExpr ${ }^{\mathrm{a}}$ \\
\hline Immune response & 18 & $<0.001$ & OntoExpr \\
\hline Response to chemical stimulus & 12 & 0.005 & OntoExpr \\
\hline MAPKKK cascade & 8 & $<0.001$ & OntoExpr \\
\hline Lysosome & 8 & $<0.001$ & GOTM ${ }^{b}$ \\
\hline Endopeptidase inhibitor activity & 6 & 0.005 & GOTM \\
\hline Lipid catabolism & 5 & 0.004 & GOTM \\
\hline Microsome & 5 & 0.008 & OntoExpr \\
\hline Xenobiotic metabolic process & 4 & $<0.001$ & OntoExpr \\
\hline B-cell-mediated immunity & 4 & 0.002 & GOTM \\
\hline Monooxygenase activity & 4 & 0.006 & OntoExpr \\
\hline Oxygen and reactive oxygen species metabolic process & 4 & 0.007 & OntoExpr \\
\hline Helicase activity & 4 & 0.008 & OntoExpr \\
\hline Aromatic compound metabolic process & 4 & 0.011 & OntoExpr \\
\hline Antigen processing and presentation of endogenous antigen & 3 & 0.001 & GOTM \\
\hline Tricarboxylic acid cycle & 3 & 0.002 & GOTM \\
\hline Mitochondrial matrix & 3 & 0.005 & OntoExpr \\
\hline
\end{tabular}

${ }^{\mathrm{a} O n t o E x p r e s s .}{ }^{\mathrm{b}} \mathrm{GO}$ tree machine.

genes), and 'ECM-receptor interaction' (eight genes). The genes assigned to these pathways were almost identical with six of them coding for collagens. Three tubulin genes (TUBB, TUBA1, TUBA1B) were assigned to the gap junction pathway. Pathways with the highest numbers of assigned genes showing higher mRNA levels at dioestrus were 'focal adhesion' (five genes) and with four assigned genes respectively three metabolic pathways ('citrate cycle', 'reductive carboxylate cycle', 'starch and sucrose metabolism'), 'complement and coagulation cascades' and 'antigen processing and presentation'. Figure 2 shows pathways that contain genes of both types of regulation.

The genes with elevated mRNA levels either at oestrus or at dioestrus were further analysed with the 'functional annotation clustering' tool of the Database for Annotation, Visualization and Integrated Discovery (DAVID; Dennis et al. 2003). The results of this integrated analysis of different functional databases (e.g. GO, KEGG pathways, SP-PIR keywords) are clusters of more or less enriched members with overlapping sets of genes, thus resulting in a significant cluster enrichment score (geometric mean in log scale of member's Fisher exact $P$ values in a corresponding annotation cluster). An enrichment score of 1.3 corresponds to a $P$ value of 0.05 . The results of this analysis are summarised in Tables 4 and 5, where the most informative terms, the number of genes assigned to the cluster and the enrichment score of the cluster are shown. At oestrus, most significant clusters are containing members related to extracellular region, focal adhesion, transport, morphogenesis, regulation of cell growth, protein transport and cytoskeleton. At dioestrus, the highest enrichment scores were found for response to stimulus, immune response, glycoprotein, lysosome, transcription factor activity and carbohydrate metabolism.

Using Pathway Architect software (version 2.0.1, Stratagene, Heidelberg, Germany), interaction networks were built for genes up-regulated at oestrus (self-organising tree algorithm, SOTA clusters 3, 4, 5, and 6 in Fig. 1) and genes up-regulated at dioestrus (SOTA clusters 1 and 2 in Fig. 1) respectively. Networks were drawn based on the different types of interactions like binding, regulation, expression, transport, assignment to a protein family or a biological process. Furthermore, interactions with small molecules and proteins not regulated, but substantially contributing to the network, were also included. Proteins were assigned to their primary cellular localisation. Figure 3 (see also Supplement to Figure 3, which is available online at www.reproduction-online/supplemental/) shows the interaction network for the genes with higher mRNA concentrations at oestrus, of which 67 could be assigned. In Fig. 4 (see also Supplement to Figure 4, which is available online at www.reproductiononline/supplemental/), the network of genes with elevated mRNA levels at dioestrus (103 genes assigned) is shown. For further details on the interactions and the genes, see the supplemental material (navigable HTML files).

For six selected genes (claudin 10 (CLDN10), CLDN4, galectin-1 (LGALS1), melanoma antigen family $\mathrm{D}, 1$ (MAGED1), prohormone convertase 5 (PCSK5) and tight junction protein 1 (TJP1)), in situ hybridisation with the bovine endometrial tissue sections corresponding to those used for microarray analyses was carried out (Fig. 5). These six genes were selected due to their potential role in cell adhesion and regulation of implantation. As revealed by the array hybridisation, CLDN10, LGALS1, MAGED1 and PCSK5 mRNAs showed the highest levels at oestrus, TJP1 at day 12 and CLDN4 at day 18 (P4 high). A specific pattern of mRNA distribution in the endometrium was found for each of these genes. The hybridisation signal was always confined to the cells of the endometrium. No mRNA staining was seen in the myometrium or the serosa. No specific signal was observed in the sections hybridised with the sense strand or in sections that were incubated with buffer only instead of the oligoprobes. Table 6 summarises the results of the mRNA localisation experiments. 


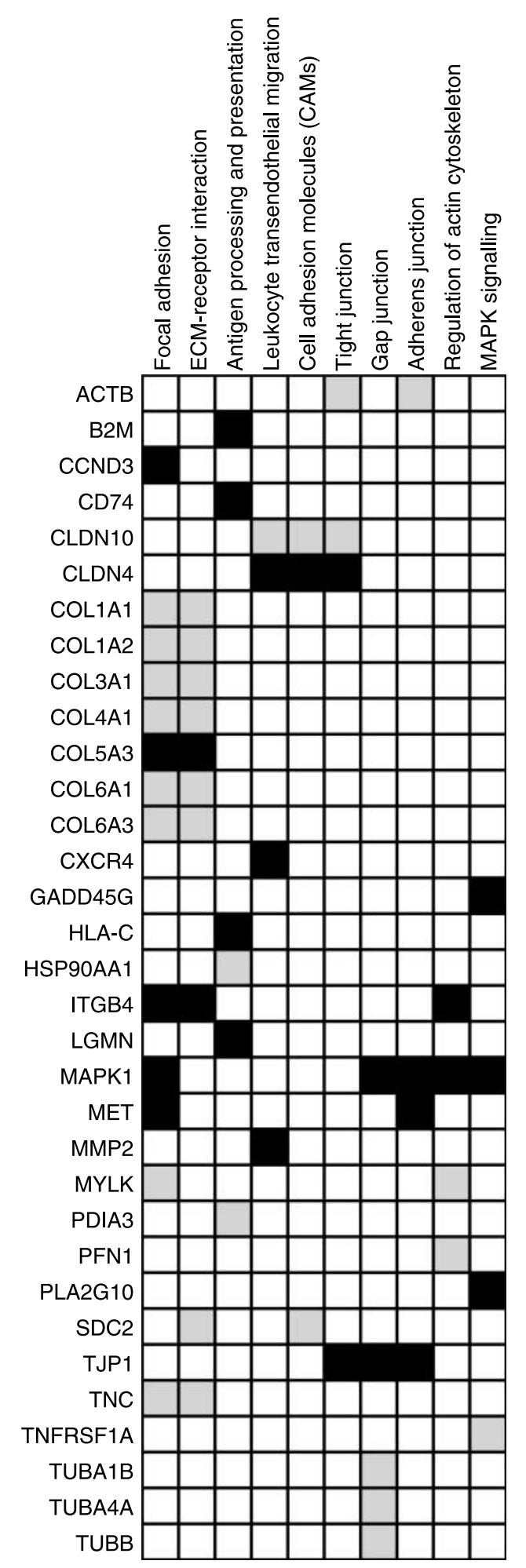

Figure 2 Results of KEGG pathway search. KEGG pathways were searched for the differentially expressed genes. Pathways containing both genes with the highest mRNA levels at oestrus and genes with the highest mRNA levels at dioestrus are shown. Grey boxes, genes up-regulated at oestrus; black boxes, genes up-regulated at dioestrus.

\section{Discussion}

After an initial investigation of the differential gene expression in the bovine endometrium between the oestrus and dioestrus stages in our previous study (Bauersachs et al. 2005), the present work provides the first study of dynamic changes in the mRNA expression profiles between several time points of the oestrous cycle. As in our earlier studies, the intercaruncular endometrium was used for gene expression analyses, since there are distinct differences between the caruncular and intercaruncular endometrium regarding morphology and function. Most notably, the caruncles contain no uterine glands. After embryo implantation, the caruncles grow rapidly and form individual placentomes, which are responsible for gaseous and small molecule exchange. Because the uterine glands play an important role in the supply of large molecules to the embryo before and after implantation (Atkinson et al. 1984), the intercaruncular tissue samples were preferred for gene expression analyses.

For the oestrous stage, two groups of samples were collected corresponding to early oestrus (around oestradiol peak) and late oestrus (after LH surge). Furthermore, the early luteal phase, the dioestrus phase and the late luteal phase were included. The latter cycle stage was analysed because the implantation of the bovine embryo is initiated at day 18, which requires appropriate conditioning of the endometrium (Bauersachs et al. 2006, Klein et al. 2006).

The statistical analysis of the microarray data as well as the hierarchical clustering hardly showed any significant differences between the early (18P4L) and the late oestrus samples (day 0). Either no major differences in the mRNA levels between the early and late oestrus exist or the day 0 and day $18 \mathrm{P} 4 \mathrm{~L}$ groups were not homogeneous enough regarding their hormone levels to detect significant differences in the endometrial transcriptome profiles. Interindividual variation is clearly an important issue, since genes like TGFB1 (transforming growth factor $\beta 1$ ) show only transient mRNA up-regulation for a few hours after oestrogen induction (Takahashi et al. 1994). The most pronounced differences were found between the oestrus and dioestrus stages. The gene expression at day 3.5 is an intermediate between oestrus and dioestrus for most of the analysed genes either increasing or decreasing during the luteal phase. In addition to the marked differences between oestrus and dioestrus, significant differences were found between the mid- and late luteal phase with the mRNA levels mainly decreasing during the late luteal phase in correlation with lower $\mathrm{P}_{4}$ levels in the day $18 \mathrm{P} 4 \mathrm{H}$ group compared with the day 12 group.

The analysis of GO categories, KEGG pathways and functional annotation clustering revealed quantitatively enriched biological processes and molecular functions, which are distinct for the ovulatory and the luteal phases. In accordance with our previous results (Bauersachs et al. 
Table 4 Results of functional annotation clustering for genes with higher mRNA levels at oestrus.

\begin{tabular}{|c|c|c|}
\hline Cluster description & Genes & Score \\
\hline Signal peptide/glycoprotein/extracellular region & 40 & 6.13 \\
\hline Structural molecule activity/extracellular matrix/coiled coil/focal adhesion/cell communication & 38 & 4.09 \\
\hline Morphogenesis/regulation of cell growth/IGF binding & 12 & 3.74 \\
\hline Cytoplasm/transport & 40 & 2.41 \\
\hline Acetylation/cytoskeleton/cytoskeletal protein binding & 18 & 2.04 \\
\hline $\begin{array}{l}\text { Transporter activity/generation of precursor metabolites and energy/thioredoxin fold/protein disulphide } \\
\text { isomerase activity }\end{array}$ & 12 & 2.01 \\
\hline Establishment of protein localisation/endoplasmic reticulum & 13 & 1.80 \\
\hline Cell organisation and biogenesis/purine nucleotide binding/cytoskeleton/hydrolase activity & 39 & 1.71 \\
\hline Cell motility & 5 & 1.32 \\
\hline G-protein-coupled receptor protein signalling pathway/neuropeptide & 5 & 1.23 \\
\hline
\end{tabular}

2005), a number of mRNAs coding for the ECM proteins and the components of the cytoskeleton were found as enriched at oestrus, indicating a remodelling of the ECM in the endometrium and changes of the cytoskeleton of endometrial cells. The lower mRNA levels of collagen genes at dioestrus are in line with the results of a recent study (Yamada et al. 2002) where a decrease in collagen fibres has been observed during the pre-implantation phase in the bovine endometrium. This also fits well with the expression profiles of MMP2 (SOTA cluster 2) and MEP1B (SOTA cluster 1) mRNAs coding for proteases involved in the ECM degradation (Kaushal et al. 1994). MEP1B mRNA showed the highest levels at days 12 and 18. The MMP2 mRNA expression profile was not typical for cluster 2, since concentration was the highest at day 3.5 and low at all other analysed time points. The expression profiles of TIMP1 (cluster 3) and TIMP2 (cluster 1) mRNAs, coding for inhibitors of matrix metalloproteinases, were opposite to MMP2 with the lowest levels at day 3.5. The mRNA levels of most collagen genes and other constituents of the ECM were similar from days $18 \mathrm{P} 4 \mathrm{~L}$ to 3.5 and low at days 12 and 18 (clusters 5 and 6). HTRA1 mRNA codes for a serine protease that is activated by C-propeptides of fibrillar collagens (Murwantoko et al. 2004) and has been shown to cleave TGFB1 and other members of the TGFB family (Oka et al. 2004). The mRNA expression profile (cluster 6) was similar to those of fibrillar collagens. In addition, the expression of HTRA1 has been shown in the human placenta at the maternal-trophoblast interface (Nie et al. 2006). The mRNA expression profiles of all these genes suggest a complex regulation of the ECM remodelling in the bovine endometrium during the oestrous cycle.

Probably, in connection with increased ECM synthesis, genes relevant for protein folding and secretion were enriched at oestrus. For example, SERPINH1 (serpin peptidase inhibitor, clade $\mathrm{H}$, member 1 ), also known as HSP47, has been described as collagen-binding protein of the endoplasmic reticulum involved in collagen processing and secretion (Nagata 1996). Furthermore, transcripts of the genes related to the regulation of cell growth were overrepresented at oestrus. These include mRNAs of a number of IGF-binding proteins, which are important for the regulation of cell growth. The interaction network shows that they are probably regulated by TGFB1, retinoic acid (RA) and oestrogen in a complex manner. Oestrogen may mediate a number of its effects on the endometrium via induction of TGFB1 and RA. Direct induction of expression of RA biosynthetic enzymes has been found in the rat uterus (Li et al. 2004). In addition, prostaglandin E2 $\alpha$ (PGE2a), interferons (IFNG) and tumour necrosis factor- $\alpha$ are suggested as important regulators by the oestrus interaction network. A number of genes with higher mRNA levels at oestrus were found in the context of the process focal adhesion formation. Genes coding for ECM proteins and components of the cytoskeleton, which are linked via paxillin, are involved in this process. A possible candidate for the regulation of cytoskeleton proteins is polo-like kinase 2 (PLK2; SOTA cluster 5), also known as serum-inducible kinase SNK. PLK2 has been shown to play a role in the remodelling of synapses via phosphorylation of spine-associated Rap guanosine

Table 5 Results of functional annotation clustering for genes with higher mRNA levels at dioestrus.

\begin{tabular}{lrr}
\hline Cluster description & Genes & Score \\
\hline Response to stimulus/immune response & 38 & 3.40 \\
Glycoprotein/signal peptide & 44 & 3.39 \\
Vacuole/lysosome & 8 & 3.21 \\
Humoral immune response/complement and coagulation cascades & 6 & 1.95 \\
Transcription factor activity/interferon regulatory factor & 20 & 1.69 \\
Catabolism/carbohydrate metabolism/TCA cycle & 15 & 1.62 \\
Response to chemical stimulus/endoplasmic reticulum/monooxygenase & 10 \\
Enzyme regulator activity/endopeptidase inhibitor activity & 4 & 1.55 \\
Immune response/antigen processing and presentation & 14 \\
Generation of precursor metabolites and energy/mitochondrion/TCA cycle & 1.52 \\
\hline
\end{tabular}




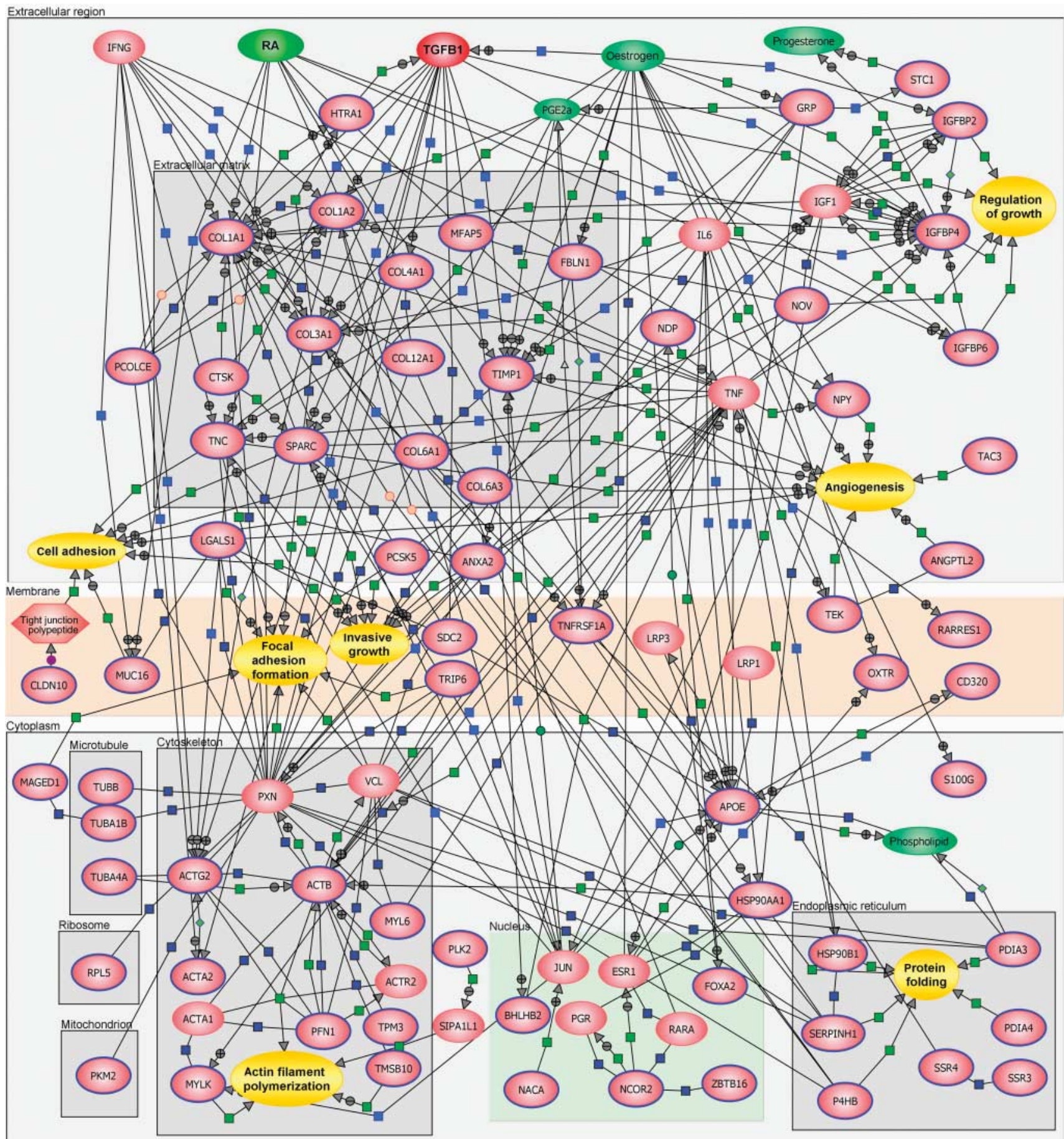

Figure 3 Interaction network of genes with the highest mRNA levels at oestrus. Proteins (red) are assigned to their primary cellular localisations. Proteins with higher mRNA levels at oestrus are highlighted in blue. Small molecules are in green and biological processes in yellow. Interaction types: dark blue squares, binding; light blue squares, expression; green squares, regulation; green circles, promoter binding; orange circles, protein modification; purple circles, member; green triangle, transport; cyan diamond, metabolism. Further information on nodes and interactions can be found in Supplement to Fig. 3 (navigable HTML, which is available online at www.reproduction-online/supplemental/).

triphosphatase-activating protein (SPAR), a postsynaptic actin regulatory protein, leading to the degradation of SPAR (Pak \& Sheng 2003). PLK2 could play a similar role in the modulation of actin filament polymerisation in the bovine endometrium. A number of genes such as LGALS1, tenascin C (TNC), osteonectin (SPARC), PCSK5, gastrinreleasing peptide, annexin $\mathrm{A} 2$ and nephroblastoma overexpressed gene; SOTA clusters 5, 5, 6, 4, 3, 5, 5) have been described as positively involved in the regulation of the process 'invasive growth'. The decreased 


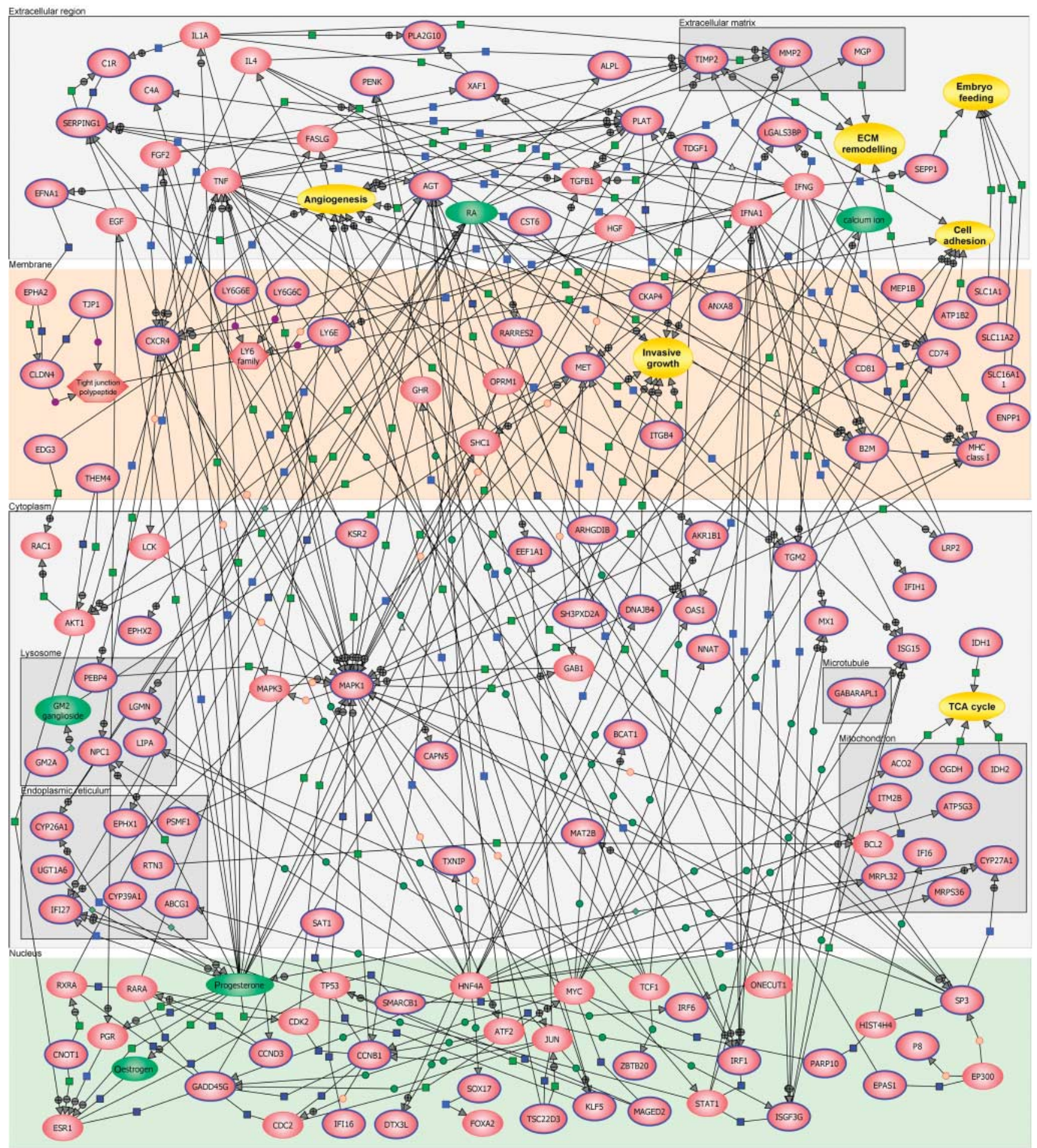

Figure 4 Interaction network of genes with the highest mRNA levels at dioestrus. Proteins (red) are assigned to their primary cellular localisations. Proteins with higher mRNA levels at dioestrus are highlighted in blue. Small molecules are in green and biological processes in yellow. Interaction types: dark blue squares, binding; light blue squares, expression; green squares, regulation; green circles, promoter binding; orange circles, protein modification; purple circles, member; green triangle, transport; cyan diamond, metabolism. Further information on nodes and interactions can be found in Supplement to Fig. 4 (navigable HTML, which is available online at www.reproduction-online/supplemental/). 


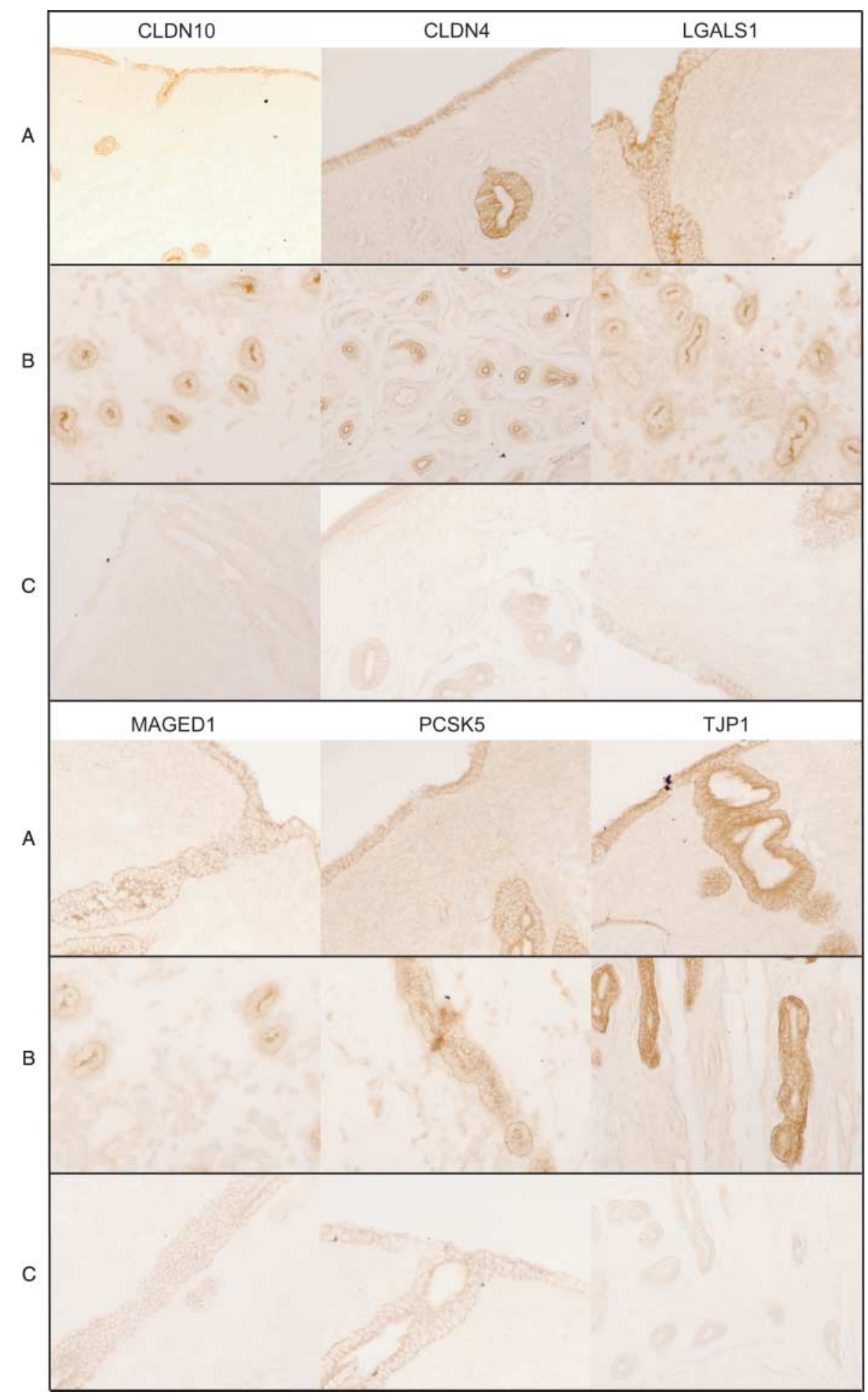

Figure 5 Localisation of mRNA expression of selected genes in the endometrial tissue samples by in situ hybridisation. Endometrial tissue samples were obtained from animals slaughtered at different days of oestrous cycle for the detection of CLDN10, LGALS1, MAGED1 and PCSK5 mRNAs at oestrus (day 0) or CLDN4 and TJP1 mRNAs at dioestrus (days $18 \mathrm{P} 4 \mathrm{H}$ and 12 respectively). Endometrial sections $(\mathrm{A})$ near the epithelial surface, (B) of the deep uterine glands and $(\mathrm{C})$ the corresponding sense controls are shown.
mRNA levels of these genes during the luteal phase may be associated with the regulation of non-invasive implantation in cattle. Furthermore, a couple of genes are involved in the cell adhesion processes. Most importantly, MUC16 mRNA is down-regulated during the luteal phase (cluster 4). MUC16 protein has been shown to prevent initial trophoblast cell adhesion and is lost in the human endometrium during the receptive phase (Gipson et al. 2007).

It has been known for a long time that uterine blood flow substantially changes during the oestrous cycle with increased blood flow during oestrus (Greiss \& Anderson 1969). In this context, a number of genes up-regulated at oestrus are linked with the process angiogenesis in the 
Table 6 Localisation of mRNA expression of selected mRNAs in endometrial tissue samples by in situ hybridisation.

\begin{tabular}{|c|c|c|c|c|c|}
\hline \multirow[b]{2}{*}{ Gene } & \multirow[b]{2}{*}{ Gene name } & \multirow[b]{2}{*}{ Luminal epithelium } & \multicolumn{2}{|c|}{ Glandular epithelium } & \multirow[b]{2}{*}{ Stromal cells } \\
\hline & & & Superficial & Deeper glands & \\
\hline CLDN10 & Claudin 10 & ++ & ++ & + & $(+)$ \\
\hline CLDN4 & Claudin 4 & ++ & +++ & + & - \\
\hline LGALS1 & Galectin-1 & + & ++ & + & $(+)$ \\
\hline MAGED1 & Melanoma antigen family D, 1 (NRAGE) & + & $+1++$ & $(+)$ & - \\
\hline PCSK5 & Prohormone convertase 5 & + & + & $(+)$ & $(+)$ \\
\hline TJP & Tight junction protein 1 (zona occludens 1 ) & $+/++$ & ++ & +++ & $(+)$ \\
\hline
\end{tabular}

- , no staining; $(+)$, weak staining; + , moderate staining; ++ , pronounced staining; +++ , strong staining.

interaction network. Some of them are known to directly stimulate angiogenesis. ANGPTL2 (angiopoietin-like 2; cluster 5) is related to the angiopoietins and has been described to regulate endothelial cell growth (Morisada et al. 2006). TEK (TEK tyrosine kinase, endothelial; cluster 5) encodes the angiopoietin receptor TIE-2. Neuropeptide $Y$ (cluster 3 ) is a potent angiogenic factor as well as a stimulator of vascular smooth muscle proliferation (Abe et al. 2007).

For the genes up-regulated at dioestrus GO enrichment, analyses revealed predominantly several immunological processes like 'immune response', 'response to stimulus' or 'antigen processing and presentation'. Many of the corresponding genes have been described as interferon induced or were identified in our previous studies of endometrium at day 18 of pregnancy (Bauersachs et al. 2006, Klein et al. 2006). This suggests that interferons could also play a role in endometrial gene regulation during the oestrous cycle or the corresponding genes are additionally regulated through $\mathrm{P}_{4}$ effects. However, in a study of porcine endometrium, lymphocytes and other immune cells have been shown to immigrate into the endometrium during dioestrus (Kaeoket et al. 2001). In the interaction network of the luteal stage of the oestrous cycle, two of the most connective nodes are MAP kinase 1 (MAPK1; cluster 1) and $\mathrm{P}_{4}$. MAPK1 acts as an interconnection for many cellular processes and is involved in the regulation of translation and gene activation (RolliDerkinderen et al. 2003). In contrast to the 'oestrus interaction network', much more nuclear factors can be found at dioestrus correlating with the diverse functional classes of genes found as up-regulated at dioestrus.

The process angiogenesis is connected in both the interaction networks with a number of genes that predominantly have been described as positive regulators of this process. Some of them are more related to angiogenesis in the context of tumour progression and invasion, such as PLAT (tissue plasminogen activator; cluster 1), TIMP2, MMP2 and MET (hepatocyte growth factor receptor; cluster 2; Fridman et al. 1992, Diaz et al. 2002, Ma et al. 2003). Genes with higher mRNA levels during the luteal phase, which are more directly involved in angiogenesis are ephrin-A1 (EFNA1), endothelial differentiation sphingolipid G-protein-coupled receptor, 3 (EDG3), angiotensinogen $(A G T)$, endothelial PAS domain protein 1 (EPAS1; hypoxia-inducible factor 2- $\alpha$ ) and Kruppel-like factor 5 (KLF5; clusters 1, 1, 2, 1,2). AGT codes for the progenitor of angiotensin II, which has been described to function as a vasoconstrictor and to regulate fetoplacental angiogenesis in the ovine placenta (Zheng et al. 2005). EPAS1 and KLF5 code for transcription factors controlling the expression of vascular endothelial growth factor (VEGF), VEGF receptor 1 (FLT1), VEGF receptor 2 $(K D R$ ), and TEK (Takeda et al. 2004) and of platelet-derived growth factor $(P D G F)$, early growth response 1, (EGR1), plasminogen activator inhibitor type 1 (SERPINE1), inducible nitric oxide synthase $2 \mathrm{~A}$ (NOS2A), and VEGF receptor genes (Nagai et al. 2005), respectively. KLF5 is down-regulated with vascular development (Nagai et al. 2005), which is in line with the KLF5 mRNA expression profile observed in the bovine endometrium during the oestrous cycle (increased mRNA levels at days 3.5, 12, $18 \mathrm{P} 4 \mathrm{H}$; cluster 2 ) and its target TEK (highest mRNA levels at days $18 \mathrm{P} 4 \mathrm{~L}$ and 0 ; cluster 5 ).

In addition to PLAT, MET, TIMP2 and MMP2, the gene products of cystatin M (CST6; cluster 1), teratocarcinoma-derived growth factor 1 (TDGF1; cluster 1), integrin- $\beta 4$ (ITGB4; cluster 2$)$ and Dna--like heat shock protein 40 (DNAJB4; cluster 2) are connected with the process invasive growth and are thus potentially involved in the regulation of embryo implantation. Some of these genes were described as negative regulators of invasive growth, e.g. PLAT (Lin et al. 2001) and CST6 (Shridhar et al. 2004). Expression of integrins in the context of embryo implantation has been investigated in the human and mouse endometrium and in domestic animals (Aplin 1997, Burghardt et al. 2002).

A number of genes with higher mRNA levels during the luteal phase are related to the process of cell adhesion. However, only one of these genes $\angle G A L S 3 B P$, coding for galectin-3-binding protein, also known as Mac-2-binding protein (cluster 2) - is a candidate for cell-cell adhesion (Inohara et al. 1996). In one of our previous studies, LGALS3BP mRNA concentration was higher in day 18 pregnant endometrium versus day 18 control endometrium and mRNA expression localised to the luminal epithelium (Bauersachs et al. 2006).

During the pre-implantation phase, feeding of the elongating embryo is an important function of the 
endometrium. This phase corresponds to the luteal phase of the oestrous cycle. In this context, a number of genes related to several metabolic functions were up-regulated during the luteal phase, such as mitochondrial aconitase 2 (ACO2), oxoglutarate dehydrogenase $(O G D H)$, isocitrate dehydrogenase 1 (IDH1) and IDH2 (clusters 1, 2, $1,1)$, which are involved in the TCA cycle. Furthermore, genes encoding different transporters were identified as up-regulated during the luteal phase. SLC1A1 (cluster 1) codes for a glutamate transporter that has been detected in the human placenta and suggested to be involved in the active transport of glutamate between the fetal and maternal blood circulation (Noorlander et al. 2004). SLC11A2 (cluster 2) encodes a metal ion transporter expressed in the human placenta (Chong et al. 2005). SLC16A1 (cluster 2) codes for monocarboxylate transporter 8 , described as a powerful and specific thyroid hormone (TH) membrane transporter with an important role in the $\mathrm{TH}$ transport during fetal development and a specific role in the human placental development (Chan et al. 2006). Selenoprotein P (SEPP1; cluster 1) is a selenium supply protein (Saito \& Takahashi 2002) and ectonucleotide pyrophosphatase/phosphodiesterase 1 (ENPP1; cluster 2) regulates extracellular pyrophosphate concentrations (Hessle et al. 2002).

The probable functions of the six genes, which were selected for mRNA in situ hybridisation, are discussed in the following in detail. These genes were selected based on their potential role for the regulation of the preparation of the endometrium for embryo implantation. In cattle, implantation is non-invasive (placenta epitheliochorealis). The luminal epithelium of the endometrium remains mainly intact except for the formation of giant cells, which are the fusion products of the epithelial and trophoblast cells (Wathes \& Wooding 1980). The exchange of nutrients takes place by diffusion through the epithelium, providing an appropriate environment for the developing embryo. Tight junction barriers of the luminal epithelium regulate the passage of ions, water and molecules through the paracellular space (Gonzalez- Mariscal et al. 2003) and separate the very different maternal and embryonic milieu (Hees \& Sinowatz 1992). Three mRNAs coding for tight junction proteins show differential expression during the oestrous cycle: CLDN10, CLDN4 and TJP1 (zona occludens 1). Claudins, for example, are tight junction-associated adhesion molecules involved in the formation of epithelial barriers and are directly involved in intercellular sealing in the simple epithelia (Tsukita \& Furuse 2002). The mRNA coding for CLDN10 is strongly up-regulated at oestrus (cluster 5), whereas the mRNA level of CLDN4 is increased at dioestrus with the highest levels during the late luteal phase (cluster 1). TJP1 mRNA expression showed the lowest levels at day 0 , increased until day 12 and decreased thereafter (cluster 2). Both the claudin mRNAs are mainly localised in the luminal epithelium and the superficial glands. In situ hybridisation for TJP1 mRNA showed in addition strong staining of the deeper endometrial glands. In mice, Tjp1 has been shown to take part in the formation of a temporary barrier in the cells of the primary decidual zone that restricts the passage of injurious stimuli such as maternal immunoglobulins to the embryo (Wang et al. 2004). The differential regulation of mRNAs coding for tight junction proteins suggests an important role regarding the preparation of the endometrium for embryo implantation and protection of the embryo from the maternal immune system.

The proprotein convertase subtilisin/kexin type 5 (PCSK5), also known as prohormone convertase 5 or protease PC6, has been shown to convert inactive precursors to their mature active forms (Seidah \& Chretien 1999). One of the proteins that first occur as immature precursors and become activated by PCSK5 is VEGF (Popovici et al. 2000), which is known to be involved in the regulation of angiogenesis (Carmeliet 2005; see above). Strong induction of PCSK5 protein has been shown in uterine stromal cells specifically at the site of embryo attachment during early pregnancy in mice and during the phase of uterine receptivity and at implantation in primates. In vivo blocking of uterine production of PCSK5 protein in mice resulted in total inhibition of implantation (Nie et al. 2003, 2005). In contrast, in our present study, the mRNA expression of PCSK5 was the highest at oestrus and decreased during the luteal phase (cluster 3). PCSK5 may be an example for species-specific differences of gene expression regulation due to its essential role in the regulation of invasive type of implantation. Furthermore, in situ hybridisation revealed a stronger staining in the luminal epithelial cells and the superficial glands than in the stromal cells. The higher mRNA levels observed during oestrus may be associated with angiogenesis and remodelling of the ECM, since PCSK5 has been shown to play a central role in the MT-MMP-MMP-2 proteolytic cascade (Stawowy et al. 2005).

MAGED1 mRNA was up-regulated at oestrus (day 0) and down-regulated at dioestrus (cluster 5) and mainly localised in the superficial uterine glands and the luminal epithelium. While the melanoma antigen family genes, MAGEA and MAGEB, are silent in the normal tissues with the exception of testis and placenta, the MAGED genes are expressed ubiquitously. MAGED1, also known as $N R A G E$, has been shown to alter the cytoskeleton, to inhibit cell-cell adhesion and to suppress mRNA expression and activity of MMP2 (Chu et al. 2007). Another member of this gene family, MAGED2, was found as up-regulated during dioestrus (cluster 1 ), suggesting that genes of this family may also play a role in cellular adhesion processes.

LGALS1 mRNA concentration was increased at oestrus (cluster 5). In situ hybridisation revealed pronounced staining in the superficial epithelial glands and weakto-moderate staining in other cells. The LGALS1 protein, a 
multifunctional secreted member of the galectin family, plays a pivotal role in the modulation of cell adhesion, cell growth, inflammation and angiogenesis (Almkvist \& Karlsson 2004, von Wolff et al. 2005, Thijssen et al. 2006). In the human endometrium, LGALS1 protein has been mainly localised in the stromal cells with increased expression in the late secretory phase and in the decidual tissue (von Wolff et al. 2005). The contrary spatial and temporal expression of LGALS1 in the bovine and human endometrium, i.e. between species with different types of placentation, suggests this gene as a further interesting candidate for the regulation of embryo implantation.

In conclusion, the present study revealed distinct dynamic expression profiles and identified numerous genes differentially expressed in the bovine endometrium during the oestrous cycle. The function of many of these genes, especially with respect to the preparation of the endometrium for implantation, is still unknown. The results of this study provide the basis for an in-depth analysis of individual genes/proteins or particularly interesting components of regulatory networks in the bovine uterus during the oestrous cycle and early pregnancy. From a practical perspective, knowledge of physiological changes in the endometrial transcriptome profiles during the oestrous cycle is important for the development of array-based diagnostic procedures to assess aberrant gene expression profiles associated with reduced maternal fertility or metabolic problems of high yielding dairy cows.

\section{Materials and Methods}

\section{Pretreatment of animals and collection of endometrial tissue samples}

Cyclic heifers (Bos taurus, Simmental Fleckvieh) between 17 and 31 months old were synchronised by an i.m. injection of a single dose of $500 \mu \mathrm{g}$ cloprostenol (Estrumate; Essex Tierarznei, Munich, Germany) at dioestrus. Around $60 \mathrm{~h}$ after Estrumate injection, standing heat was identified through observation of sexual behaviour (i.e. toleration, sweating, vaginal mucus). In addition, ultrasound-guided follicle monitoring was performed. Blood samples were taken 2 days before oestrus (day 0), at oestrus and just before slaughtering to determine serum $\mathrm{P}_{4}$ levels (Prakash et al. 1987). For the determination of serum LH levels by a specific RIA (Schams \& Karg 1969), blood samples were taken in intervals of 6 hours for the day 0 group. Animals were slaughtered on days 0 (oestrus, within 12 hrs after the LH surge; $n=4), 3.5(n=4), 12$ (dioestrus, luteal phase; $n=4)$ and 18 of the oestrus cycle $(n=8$; 4 with high and 4 with low serum $\mathrm{P}_{4}$ levels) respectively. After slaughter, the uterus was removed, dissected from the surrounding tissue, opened longitudinally and divided into seven sections: corpus plus caudal, middle and cranial parts of the ipsilateral and the contralateral uterine horns (Bauersachs et al. 2005). For the analyses in the present study, tissue samples of the middle part of the ipsilateral horn were used. Samples (about $250 \mathrm{mg}$ ) were carefully cut from the intercaruncular endometrium with a scalpel within $20 \mathrm{~min}$ after slaughter of the donor animal and immediately transferred into vials containing $4 \mathrm{ml}$ RNAlater (Ambion, Huntingdon, Cambridgeshire, UK) and incubated overnight at $4{ }^{\circ} \mathrm{C}$. The samples were stored at $-20^{\circ} \mathrm{C}$ until further processing. Tissue samples for in situ hybridisation were collected from the same animals and the same location within the uterus and fixed by immersion in formalin (3.7\%) and then routinely processed for embedding in paraffin. All experiments with animals were conducted with permission from the local veterinary authorities and in accord with the accepted standards of humane animal care.

\section{Preparation of cDNA arrays and CDNA array hybridisation}

The generation of the BOE array has been described previously (Bauersachs et al. 2007). Fifteen microlitres of the PCR products of the cDNA fragments and $15 \mu \mathrm{l}$ long oligonucleotides (50 ng/ $\mu \mathrm{l}$; Operon, Cologne, Germany) were transferred to 384-well microtitre plates (Abgene, Epsom, Surrey, UK) containing $15 \mu \mathrm{l}$ twofold spotting buffer (40 mM Tris- $\mathrm{HCl}(\mathrm{pH} 8.0), 2 \mathrm{M} \mathrm{NaCl}$, 2 mM EDTA, bromophenol blue). A total of 1344 cDNA fragments and 96 oligonucleotides were spotted onto nylon membranes (Nytran Plus; Whatman Schleicher \& Schuell, Dassel, Germany) on an area of $20 \times 50 \mathrm{~mm}$ using a microarray robot (Omnigrid Accent; Gene Machines, Ann Arbor, MI, USA) and solid pins (SSP015, diameter 0.015 inch; Telechem International, Sunnyvale, CA, USA). Spotting was done six times for each PCR product on the same position for sufficient and equal application. Thirtytwo arrays were produced simultaneously. The spotted DNA was denatured by incubation with $0.5 \mathrm{M} \mathrm{NaOH}$ for $20 \mathrm{~min}$ at room temperature. Subsequently, DNA was immobilised by baking for $30 \mathrm{~min}$ at $80{ }^{\circ} \mathrm{C}$ and u.v. crosslinking $\left(120 \mathrm{~mJ} / \mathrm{cm}^{2}\right.$; XL-1500 u.v. crosslinker; Spectronics Corp., Westbury, NY, USA). Total RNA was isolated from 20 endometrial tissue samples using TRIzol (Invitrogen), according to the manufacturer's instructions. The quantity and quality of total RNA were determined by spectrometry and agarose gel electrophoresis respectively. Doublestranded (ds) cDNA was synthesised starting with $50 \mu \mathrm{g}$ total RNA using Superscript III (200 U/ $\mu \mathrm{l}$, Invitrogen) and 50 pmol cDNA synthesis primer $\left(\mathrm{GAGAT}_{20} \mathrm{VN} ; \mathrm{V}=\mathrm{A}, \mathrm{C}\right.$ or $\left.\mathrm{G}\right)$ for first-strand synthesis. The second strand was synthesised with Escherichia coli DNA polymerase I (40 U), E. coli RNase H (2 U) and E. coli DNA ligase (10 U; Invitrogen), according to the manufacturer's instructions. Ribosomal and other residual RNAs were digested with $5 \mu$ l RNase $(0.5 \mathrm{mg} / \mu \mathrm{l}$, DNase free, from bovine pancreas; Roche Diagnostics) for $90 \mathrm{~min}$ at $37^{\circ} \mathrm{C}$. Remaining nucleotides and primers were removed using Microspin S200-HR spin columns (GE Healthcare Life Science, Munich, Germany). Subsequently, cDNA was precipitated with $15 \mu \mathrm{l}$ of $3 \mathrm{M} \mathrm{NaOAc}$ and $150 \mu \mathrm{l}$ isopropanol. Dry sediment was solubilised in $20 \mu \mathrm{l}$ of $0.5 \times$ Tris/HCl-EDTA (TE) buffer ( $\mathrm{pH} 8.0)$. The quality of cDNA was determined by agarose gel electrophoresis.

${ }^{33} \mathrm{P}$-labelled cDNA probes (four for each group) were generated from ds cDNA corresponding to 7.5-15 $\mu \mathrm{g}$ total RNA. CDNA was heat denatured for $10 \mathrm{~min}$ at $96^{\circ} \mathrm{C}$ and then chilled on ice. High prime reaction mixture (Roche), dNTP mixture (dCTP final concentration $10 \mathrm{pmol} / \mu \mathrm{l}$, dATP, dGTP and dTTP final concentration each $100 \mathrm{pmol} / \mu \mathrm{l}$ ) and $90 \mu \mathrm{Ci} \alpha-{ }^{33} \mathrm{PdCTP}$ were added to a final volume of $20 \mu \mathrm{l}$. Reaction mixtures were incubated for $1 \mathrm{~h}$ at 
$37^{\circ} \mathrm{C}$, heat inactivated for $20 \mathrm{~min}$ at $65^{\circ} \mathrm{C}$ and purified with ProbeQuant G50 spin columns (GE Healthcare Life Science) to remove unincorporated nucleotides and to estimate labelling efficiency. Hybridisation was done as follows: pre-hybridisation was done for five arrays together in one $15 \mathrm{~cm}$ glass hybridisation bottle: $2 \times 10 \mathrm{~min} 10 \mathrm{ml} 0.1 \times \mathrm{PBS} / 1 \% \mathrm{SDS}$ at $85^{\circ} \mathrm{C} ; 3 \times 10 \mathrm{~min}$ $10 \mathrm{ml} 1 \times \mathrm{PBS} / 10 \%$ SDS at $65^{\circ} \mathrm{C}$ and $1 \times 10 \mathrm{~min} 10 \mathrm{ml}$ $1 \times \mathrm{PBS} / 10 \%$ SDS at room temperature. Hybridisation probes were denatured for $15 \mathrm{~min}$ at $96{ }^{\circ} \mathrm{C}$ immediately before adding them to the hybridisation solution. Hybridisation was done in plastic vials (Poly-Q vials, $18 \mathrm{ml}$; Beckman Coulter, Munich, Germany) in $2.5 \mathrm{ml} 1 \times \mathrm{PBS}$ (pH 7.5)/10\% SDS for $47 \mathrm{~h}$ at $65^{\circ} \mathrm{C}$. After hybridisation, the arrays were put together in $15 \mathrm{~cm}$ glass hybridisation bottles, five arrays per bottle, and washed as follows: $3 \times 5 \mathrm{~min} 10 \mathrm{ml} 1 \times \mathrm{PBS} / 10 \%$ SDS at $65^{\circ} \mathrm{C} ; 3 \times 10 \mathrm{~min} 10 \mathrm{ml}$ $1 \times \mathrm{PBS} / 10 \% \mathrm{SDS}$ at $65^{\circ} \mathrm{C} ; 3 \times 10 \mathrm{~min} 10 \mathrm{ml} 0.1 \times \mathrm{PBS} / 1 \% \mathrm{SDS}$ at $65{ }^{\circ} \mathrm{C}$ and $3 \times 5 \mathrm{~min} 10 \mathrm{ml} 1 \times \mathrm{PBS} / 1 \% \mathrm{SDS} / 2 \mathrm{mM}$ EDTA at $30{ }^{\circ} \mathrm{C}$. Filters were dried by baking at $80{ }^{\circ} \mathrm{C}$ for $20 \mathrm{~min}$. The filters were exposed to an imaging plate BAS-SR (Fuji Photo Film Co., purchased from Raytest, Straubenhardt, Germany). Imaging plates were scanned with a phosphor imager (Typhoon Imager; GE Healthcare Life Science). Labelling and hybridisation were done in parallel for all the 20 samples.

\section{Analysis of array data}

The data discussed in this publication have been deposited in NCBI's Gene Expression Omnibus (GEO, http://www.ncbi.nlm. nih.gov/geo/) and are accessible through GEO Series accession number GSE8337. Array evaluation was done using AIDA Image Analyzer software (version 3.52; Raytest). Background was subtracted with the 'lowest grid dot' function. Raw data were normalised with the BioConductor package vsn (Huber et al. 2002). For quality control, normalised data were analysed with a distance matrix and a heatmap based on pair-wise distances (BioConducter package geneplotter). Significance analysis was performed using the 'significance analysis of microarrays' method (SAM, Multiclass; Tusher et al. 2001). Data from cDNAs with significant changes during the oestrous cycle was used for cluster analyses with MultiExperiment Viewer 4.0 (Saeed et al. 2003). For hierarchical clustering of genes and samples, $\mathrm{HCL}$ support trees were used based on mean centred values ( $\log _{2}$ value of a gene minus mean of all $19 \log _{2}$ values of this gene). For SOTA (cluster analysis for identification of similar expression profiles), means for each of the five groups were calculated and mean centred (mean $\log _{2}$ value group minus mean of all the five groups). Quantitatively enriched GO categories were identified using GOTM (Zhang et al. 2004) and OntoExpress (Draghici et al. 2003). Integrated analysis of different functional databases was done using the 'functional annotation clustering' tool of the DAVID (Dennis et al. 2003). Genes were assigned to KEGG pathways (http://www.genome.ad.jp/kegg/tool/search_pathway. html) based on the Entrez Gene ID of the putative human orthologous gene. Interaction networks were built using Pathway Architect software (version 2.0.1; Stratagene). Most of the interactions and cellular localisations provided by the Pathway Architect databases were checked. Additional interactions found in the literature were assigned to the network.

\section{Quantitative real-time RT-PCR}

Real-time RT-PCR was performed as described previously (Ulbrich et al. 2004). The following primers (PCR product length in parentheses) were used to amplify specific fragments referring to selected mRNAs: CLDN10 (forward: 5'-CATTTCATGCCAATCAGGG, reverse: 5'-CGCTGGACGGTTACATCC (97 bp)), IRF1 (forward: 5'-TCTGCTTAATGAACCTGGGG, reverse: 5'-TATCAGGCCAATATAACCCCC (103 bp)), LGALS1 (forward: 5'-AGTGTCGTGGAGGTATGCATC, reverse: 5'-TGAAGTCACCACCTGCAGAC (133 bp)), PCKS5 (forward: 5'-ATGTCAAACAGCTGGCGTC, reverse: 5'-TACTTCATGGAGGAGCGGAG (115 bp)), PLA2 G10 (forward: 5'-TTGTGTGGGAACTACTCACCC, reverse: 5'-TCAAACTGGAAACCAAACTGG (211 bp)), PFN1 (forward: 5'-CCCCAACCTTCAATATCACG, reverse: 5'-TTTCTTGTTGATCATACCGCC (95 bp)), SERPING1 (forward: 5'-AAATGACAGCACAGCCAGC, reverse: 5'-CTATCTTCCACTTGGCGCTC (149 bp)), STC1 (forward: 5'-CATATTCGTCCATGGCCAG, reverse: 5'-GGTTGCCCCAGTAGAGTTAGC (124 bp)), TDGF1 (forward: 5'-TCATGCAGATTTCATGACCTG, reverse: 5'-TTTAGGGACCACAGGGAAATC (110 bp)), TNC (forward: 5'-ACT- TTAGCTCCTGCCAGAYG, reverse: 5'-TAAGTTTCCGGGGACAACTG (124 bp)), TJP1 (forward: 5'-GCTCTAAAATCATCCGACTCCTC, reverse: 5'-ACAGAAACACAGTTTGCTC-CAAC (104 bp)) and 18S rRNA (forward: 5'-AAGTCTTTGGGTTCCGGG, reverse: 5' GGACATCTAAGGGCATCACA (365 bp)). All amplified PCR fragments were sequenced to verify the resulting PCR product (MWG-Biotech, Ebersberg, Germany). The annealing temperature (AT) and the appropriate fluorescence acquisition (FA) points for quantification within the fourth step of the amplification segment were as follows: $18 \mathrm{~S}$ rRNA (AT $60{ }^{\circ} \mathrm{C}$, FA $82{ }^{\circ} \mathrm{C}$ ); IRF1, LGALS1, PLA2G10, TNC, PFN1 (AT $60^{\circ} \mathrm{C}$, FA $80^{\circ} \mathrm{C}$ ); CLDN10 (AT $64^{\circ} \mathrm{C}$, FA $80^{\circ} \mathrm{C}$ ); PCKS5 (AT $66^{\circ} \mathrm{C}$, FA $74{ }^{\circ} \mathrm{C}$ ); SERPING1 (AT $64{ }^{\circ} \mathrm{C}$, FA $85^{\circ} \mathrm{C}$ ); STC1 (AT $66^{\circ} \mathrm{C}$, FA $74^{\circ} \mathrm{C}$ ); TDGF1 (AT $60{ }^{\circ} \mathrm{C}$, FA $74{ }^{\circ} \mathrm{C}$ ) and TJP1 (AT $64^{\circ} \mathrm{C}$, FA $77^{\circ} \mathrm{C}$ ). The cycle number required to achieve a definite SYBR Green fluorescence signal (CP) was calculated by the second derivative maximum method (LightCycler software version 4.05; Roche Diagnostics). The CP is correlated inversely with the logarithm of the initial template concentration. The CP determined for the target genes were normalised against $18 \mathrm{~S}$ rRNA $(\Delta C P)$. Differences between the groups of the different cycle stages are expressed by the $\Delta \Delta \mathrm{CP}$ as well as the mean fold changes in relation to the cycle stage having the lowest expression (Livak \& Schmittgen 2001). The differences between the groups were analysed using one-way ANOVA. The normal distribution was tested by the Kolmogorov-Smirnov method, followed by a Holm-Sidak test to find the significant differences (Sigma-Stat, version 2.03). The overall level of significance ( $P$ value) is shown in Table 1.

\section{In situ hybridisation}

In situ hybridisation of $5 \mu \mathrm{m}$ paraffin sections of the endometrium samples was performed as described previously (Bauersachs et al. 2005). The sequences of the antisense oligonucleotides were as follows: CLDN10, 5'-ATGGGCAGGAGCCTCACTCT; CLDN4, 5'-AACATCGTCACGTCGCAGAC; 
LGALS1, 5'-TGTGCCTCCACTTCAACCCT; MAGED1, 5'-GTCATCTTCATGAATGGCAAC; PCSK5， 5'-GCAGAGCTGTAGTATCAGCTA; TJP1， 5'-AGAGGCCTCACATGAAGCCA. Negative controls were done by omitting the oligonucleotide probe and by hybridisation with sense oligonucleotide probes (complementary sequence of the antisense oligonucleotides).

\section{Declaration of interest}

The authors declare that there is no conflict of interest that would prejudice the impartiality of this scientific work.

\section{Funding}

This study was supported by the German Federal Ministry of Education and Research (BMBF), research focus FUGATO and, in part, by the German Research Council (Research Unit 478 'Mechanisms of Embryo-Maternal Communication'). This article is based on research presented at the 2 nd International Meeting on Mammalian Embryogenomics, which was sponsored by the Organisation for Economic Co-operation and Development (OECD), Le conseil Régional Ile-de-France, the Institut National de la Recherche Agronomique (INRA), Cogenics-Genome Express, Eurogentec, Proteigene, SigmaAldrich France and Diagenode sa. All authors declare that they have no relationship with any of the meeting sponsors.

\section{Acknowledgements}

We thank Myriam Weppert, Susanne Rehfeld, Susanne Schmidt, Claudia Klein, Christian Erdle and Peter Rieblinger for their assistance with animal management and sample recovery.

\section{References}

Abe K, Tilan JU \& Zukowska Z 2007 NPY and NPY receptors in vascular remodeling. Current Topics in Medicinal Chemistry 7 1704-1709.

Ace CI \& Okulicz WC 2004 Microarray profiling of progesteroneregulated endometrial genes during the rhesus monkey secretory phase. Reproductive Biology and Endocrinology 254.

Almkvist J \& Karlsson A 2004 Galectins as inflammatory mediators. Glycoconjugate Journal 19 575-581.

Aplin JD 1997 Adhesion molecules in implantation. Reviews of Reproduction 2 84-93.

Atkinson BA, King GJ \& Amoroso EC 1984 Development of the caruncular and intercaruncular regions in the bovine endometrium. Biology of Reproduction 30 763-774.

Bauersachs S, Blum H, Mallok S, Wenigerkind H, Rief S, Prelle K \& Wolf E 2003 Regulation of ipsilateral and contralateral bovine oviduct epithelial cell function in the postovulation period: a transcriptomics approach. Biology of Reproduction 68 1170-1177.

Bauersachs S, Rehfeld S, Ulbrich SE, Mallok S, Prelle K, Wenigerkind H, Einspanier R, Blum H \& Wolf E 2004 Monitoring gene expression changes in bovine oviduct epithelial cells during the oestrous cycle. Journal of Molecular Endocrinology 32 449-466.

Bauersachs S, Ulbrich SE, Gross K, Schmidt SE, Meyer HH, Einspanier R, Wenigerkind H, Vermehren M, Blum H, Sinowatz F et al. 2005 Gene expression profiling of bovine endometrium during the oestrous cycle: detection of molecular pathways involved in functional changes. Journal of Molecular Endocrinology 34 889-908.

Bauersachs S, Ulbrich SE, Gross K, Schmidt SEM, Meyer HH, Wenigerkind $H$, Vermehren $M$, Sinowatz $F$, Blum $H$, Wolf $E$ et al.
2006 Embryo-induced transcriptome changes in bovine endometrium reveal species-specific and common molecular markers of uterine receptivity. Reproduction 132 319-331.

Bauersachs S, Mitko K, Blum H \& Wolf E 2007 Technical note: Bovine oviduct and endometrium array version 1: a tailored tool for studying bovine endometrium biology and pathophysiology. Journal of Dairy Science 90 4420-4423.

Burghardt RC, Johnson GA, Jaeger LA, Ka H, Garlow JE, Spencer TE \& Bazer FW 2002 Integrins and extracellular matrix proteins at the maternal-fetal interface in domestic animals. Cells, Tissues, Organs 172 202-217.

Carmeliet P 2005 VEGF as a key mediator of angiogenesis in cancer. Oncology 69 (Supplement 3) 4-10.

Chan SY, Franklyn JA, Pemberton HN, Bulmer JN, Visser TJ, McCabe CJ \& Kilby MD 2006 Monocarboxylate transporter 8 expression in the human placenta: the effects of severe intrauterine growth restriction. Journal of Endocrinology 189 465-471.

Chong WS, Kwan PC, Chan LY, Chiu PY, Cheung TK \& Lau TK 2005 Expression of divalent metal transporter 1 (DMT1) isoforms in first trimester human placenta and embryonic tissues. Human Reproduction 20 3532-3538.

Chu CS, Xue B, Tu C, Feng ZH, Shi YH, Miao Y \& Wen CJ 2007 NRAGE suppresses metastasis of melanoma and pancreatic cancer in vitro and in vivo. Cancer Letters 250 268-275.

Dennis G Jr, Sherman BT, Hosack DA, Yang J, Gao W, Lane HC \& Lempicki RA 2003 DAVID: database for annotation, visualization, and integrated discovery. Genome Biology 4 P3.

Diaz VM, Planaguma J, Thomson TM, Reventos J \& Paciucci R 2002 Tissue plasminogen activator is required for the growth, invasion, and angiogenesis of pancreatic tumor cells. Gastroenterology 122 806-819.

Draghici S, Khatri P, Martins RP, Ostermeier GC \& Krawetz SA 2003 Global functional profiling of gene expression. Genomics 81 98-104.

Fridman R, Fuerst TR et al. 1992 Domain structure of human 72-kDa gelatinase/type IV collagenase. Characterization of proteolytic activity and identification of the tissue inhibitor of metalloproteinase-2 (TIMP-2) binding regions. Journal of Biological Chemistry 267 15398-15405.

Gipson IK, Blalock T, Tisdale A, Spurr-Michaud S, Allcorn S, StavreusEvers A \& Gemzell K 2007 MUC16 is lost from the uterodome (pinopode) surface of the receptive human endometrium: in vitro evidence that MUC16 is a barrier to trophoblast adherence. Biology of Reproduction 78 134-142.

Goff AK 2004 Steroid hormone modulation of prostaglandin secretion in the ruminant endometrium during the estrous cycle. Biology of Reproduction $7111-16$.

Gonzalez-Mariscal L, Betanzos A, Nava P \& Jaramillo BE 2003 Tight junction proteins. Progress in Biophysics and Molecular Biology $\mathbf{8 1}$ $1-44$.

Gray CA, Abbey CA, Beremand PD, Choi Y, Farmer JL, Adelson DL, Thomas TL, Bazer FW \& Spencer TE 2006 Identification of endometrial genes regulated by early pregnancy, progesterone, and interferon tau in the ovine uterus. Biology of Reproduction 74 383-394.

Greiss FC Jr \& Anderson SG 1969 Uterine vescular changes during the ovarian cycle. American Journal of Obstetrics and Gynecology 103 629-640.

Hees H \& Sinowatz F 1992 Histologie - Kurzlehrbuch der Zytologie und mikroskopischen Anatomie. Deutscher Ärzte-Verlag GmbH, Cologne: Cologne.

Hessle L, Johnson KA, Anderson HC, Narisawa S, Sali A, Goding JW, Terkeltaub R \& Millan JL 2002 Tissue-nonspecific alkaline phosphatase and plasma cell membrane glycoprotein-1 are central antagonistic regulators of bone mineralization. PNAS 99 9445-9449.

Horcajadas JA, Pellicer A \& Simon C 2007 Wide genomic analysis of human endometrial receptivity: new times, new opportunities. Human Reproduction Update 13 77-86.

Huber W, von Heydebreck A, Sultmann H, Poustka A \& Vingron M 2002 Variance stabilization applied to microarray data calibration and to the quantification of differential expression. Bioinformatics 18 (Supplement 1) S96-S104. 
Inohara H, Akahani S, Koths K \& Raz A 1996 Interactions between galectin-3 and Mac-2-binding protein mediate cell-cell adhesion. Cancer Research 56 4530-4534.

Kaeoket K, Persson E \& Dalin AM 2001 The sow endometrium at different stages of the oestrous cycle: studies on morphological changes and infiltration by cells of the immune system. Animal Reproduction Science 65 95-114.

Kaushal GP, Walker PD \& Shah SV 1994 An old enzyme with a new function: purification and characterization of a distinct matrix-degrading metalloproteinase in rat kidney cortex and its identification as meprin. Journal of Cell Biology 126 1319-1327.

Klein C, Bauersachs S et al. 2006 Monozygotic twin model reveals novel embryo-induced transcriptome changes of bovine endometrium in the preattachment period. Biology of Reproduction 74 253-264.

Li XH, Kakkad B \& Ong DE 2004 Estrogen directly induces expression of retinoic acid biosynthetic enzymes, compartmentalized between the epithelium and underlying stromal cells in rat uterus. Endocrinology 145 4756-4762.

Lin VC, Eng AS, Hen NE, Ng EH \& Chowdhury SH 2001 Effect of progesterone on the invasive properties and tumor growth of progesterone receptor-transfected breast cancer cells MDA-MB-231. Clinical Cancer Research 7 2880-2886.

Livak KJ \& Schmittgen TD 2001 Analysis of relative gene expression data using real-time quantitative PCR and the $2(-$ Delta Delta $C(\mathrm{~T}))$ method. Methods 25 402-408.

Ma PC, Maulik G, Christensen J \& Salgia R 2003 c-Met: structure, functions and potential for therapeutic inhibition. Cancer Metastasis Reviews 22 309-325.

Morisada T, Kubota Y, Urano T, Suda T \& Oike Y 2006 Angiopoietins and angiopoietin-like proteins in angiogenesis. Endothelium 13 71-79.

Murwantoko, Yano M, Ueta Y, Murasaki A, Kanda H, Oka C \& Kawaichi M 2004 Binding of proteins to the PDZ domain regulates proteolytic activity of HtrA1 serine protease. Biochemical Journal 381 895-904.

Nagai R, Suzuki T, Aizawa K, Shindo T \& Manabe I 2005 Significance of the transcription factor KLF5 in cardiovascular remodeling. Journal of Thrombosis and Haemostasis 3 1569-1576.

Nagata K 1996 Hsp47: a collagen-specific molecular chaperone. Trends in Biochemical Sciences 21 22-26.

Nie GY, Li Y, Minoura H, Findlay JK \& Salamonsen LA 2003 Specific and transient up-regulation of proprotein convertase 6 at the site of embryo implantation and identification of a unique transcript in mouse uterus during early pregnancy. Biology of Reproduction 68 439-447.

Nie G, Li Y, Wang M, Liu YX, Findlay JK \& Salamonsen LA 2005 Inhibiting uterine PC6 blocks embryo implantation: an obligatory role for a proprotein convertase in fertility. Biology of Reproduction 72 1029-1036.

Nie G, Hale K, Li Y, Manuelpillai U, Wallace EM \& Salamonsen LA 2006 Distinct expression and localization of serine protease HtrA1 in human endometrium and first-trimester placenta. Developmental Dynamics 235 3448-3455.

Noorlander CW, de Graan PN, Nikkels PG, Schrama LH \& Visser GH 2004 Distribution of glutamate transporters in the human placenta. Placenta 25 489-495.

Oka C, Tsujimoto R et al. 2004 HtrA1 serine protease inhibits signaling mediated by TGF $\beta$ family proteins. Development 131 1041-1053.

Pak DT \& Sheng M 2003 Targeted protein degradation and synapse remodeling by an inducible protein kinase. Science 302 1368-1373.

Ponnampalam AP, Weston GC, Trajstman AC, Susil B \& Rogers PA 2004 Molecular classification of human endometrial cycle stages by transcriptional profiling. Molecular Human Reproduction 10 879-893.

Popovici RM, Kao LC \& Giudice LC 2000 Discovery of new inducible genes in in vitro decidualized human endometrial stromal cells using microarray technology. Endocrinology 141 3510-3513.

Prakash BS, Meyer HH, Schallenberger E \& van de Wiel DF 1987 Development of a sensitive enzymeimmunoassay (EIA) for progesterone determination in unextracted bovine plasma using the second antibody technique. Journal of Steroid Biochemistry 28 623-627.

Roberts RM \& Bazer FW 1988 The functions of uterine secretions. Journal of Reproduction and Fertility 82 875-892.

Rolli-Derkinderen M, Machavoine F, Baraban JM, Grolleau A, Beretta L \& Dy M 2003 ERK and p38 inhibit the expression of 4E-BP1 repressor of translation through induction of Egr-1. Journal of Biological Chemistry 278 18859-18867.
Ruesse I \& Sinowatz F 1998 Weiblicher Sexualzyklus. In Lehrbuch der Embryologie der Haustiere, edn 2, pp 93-116. Berlin: Parey Buchvelag. Saeed Al, Sharov V et al. 2003 TM4: a free, open-source system for microarray data management and analysis. BioTechniques 34 374-378.

Saito Y \& Takahashi K 2002 Characterization of selenoprotein Pas a selenium supply protein. European Journal of Biochemistry $2695746-5751$.

Schams D \& Karg H 1969 Radioimmunologic determination of LH in bovine serum, with special attention to the estrous cycle. Acta Endocrinologica 61 96-103.

Seidah NG \& Chretien M 1999 Proprotein and prohormone convertases: a family of subtilases generating diverse bioactive polypeptides. Brain Research 848 45-62.

Shridhar R, Zhang J, Song J, Booth BA, Kevil CG, Sotiropoulou G, Sloane BF \& Keppler D 2004 Cystatin M suppresses the malignant phenotype of human MDA-MB-435S cells. Oncogene 23 2206-2215.

Spencer TE, Burghardt RC, Johnson GA \& Bazer FW 2004a Conceptus signals for establishment and maintenance of pregnancy. Animal Reproduction Science 82-83 537-550.

Spencer TE, Johnson GA, Burghardt RC \& Bazer FW 2004b Progesterone and placental hormone actions on the uterus: insights from domestic animals. Biology of Reproduction 71 2-10.

Stawowy P, Meyborg $\mathbf{H}$ et al. 2005 Furin-like proprotein convertases are central regulators of the membrane type matrix metalloproteinase-promatrix metalloproteinase-2 proteolytic cascade in atherosclerosis. Circulation 111 2820-2827.

Takahashi T, Eitzman B, Bossert NL, Walmer D, Sparrow K, Flanders KC, McLachlan J \& Nelson KG 1994 Transforming growth factors beta 1, beta 2 , and beta 3 messenger RNA and protein expression in mouse uterus and vagina during estrogen-induced growth: a comparison to other estrogen-regulated genes. Cell Growth and Differentiation 5 919-935.

Takeda N, Maemura K, Imai Y, Harada T, Kawanami D, Nojiri T, Manabe I \& Nagai R 2004 Endothelial PAS domain protein 1 gene promotes angiogenesis through the transactivation of both vascular endothelial growth factor and its receptor, Flt-1. Circulation Research 95 146-153.

Tan YF, Li FX, Piao YS, Sun XY \& Wang YL 2003 Global gene profiling analysis of mouse uterus during the oestrous cycle. Reproduction $\mathbf{1 2 6}$ 171-182.

Thijssen VL, Postel R, Brandwijk RJ, Dings RP, Nesmelova I, Satijn S, Vethofstad N, Nakabeppu Y, Baum LG, Bakkers J et al. 2006 Galectin-1 is essential in tumor angiogenesis and is a target for antiangiogenesis therapy. PNAS 103 15975-15980.

Tsukita S \& Furuse M 2002 Claudin-based barrier in simple and stratified cellular sheets. Current Opinion in Cell Biology 14 531-536.

Tusher VG, Tibshirani R \& Chu G 2001 Significance analysis of microarrays applied to the ionizing radiation response. PNAS $\mathbf{9 8} 5116-5121$.

Ulbrich SE, Schoenfelder M, Thoene S \& Einspanier R 2004 Hyaluronan in the bovine oviduct-modulation of synthases and receptors during the extrous cycle. Molecular and Cellular Endoctinology 214 9-18.

Wang X, Matsumoto H, Zhao X, Das SK \& Paria BC 2004 Embryonic signals direct the formation of tight junctional permeability barrier in the decidualizing stroma during embryo implantation. Journal of Cell Science 117 53-62.

Wathes DC \& Wooding FB 1980 An electron microscopic study of implantation in the cow. American Journal of Anatomy 159 285-306.

von Wolff M, Wang X, Gabius HJ \& Strowitzki T 2005 Galectin fingerprinting in human endometrium and decidua during the menstrual cycle and in early gestation. Molecular Human Reproduction 11 189-194.

Yamada O, Todoroki J, Takahashi T \& Hashizume K 2002 The dynamic expression of extracellular matrix in the bovine endometrium at implantation. Journal of Veterinary Medical Science 64 207-214.

Zhang B, Schmoyer D, Kirov S \& Snoddy J 2004 GO tree machine (GOTM): a web-based platform for interpreting sets of interesting genes using gene ontology hierarchies. BMC Bioinformatics 516.

Zheng J, Bird IM, Chen DB \& Magness RR 2005 Angiotensin II regulation of ovine fetoplacental artery endothelial functions: interactions with nitric oxide. Journal of Physiology 565 59-69.

Received 12 September 2007

First decision 15 November 2007

Accepted 21 November 2007 